聴覚誘発電位を手掛りとした作業時の大脳の聴覚情報処理に関する研究

\title{
A RESEARCH ON AUDITORY INFORMATION PROCESSING IN THE BRAIN WHEN A PERSON IS AT HIS TASK BY MEANS OF MEASUREMENT AND ANALYSIS OF AUDITORY EVOKED POTENTIAL
}

\author{
秋 田＼cjkstart剛*, 藤井 利 幸**, 平手 小太郎***, 安 岡 正 人**** \\ Takeshi AKITA, Toshiyuki FUJII, Kotaroh HIRATE \\ and Masahito YASUOKA
}

\begin{abstract}
Auditory information processing in the brain that goes on when a person is at his task is investigated by means of measurement and analysis of Auditory Evoked Potential. Results of two experiments showed that auditory information processing was affected by the priority of processing in the brain. Less quantity of auditory information processing to the sound of $50 \mathrm{dBA}$ or below seems to occur when task-related processing is prior in the brain, and that full auditory information processing to the sound of $70 \mathrm{dBA}$ or more seems to occur even if a person pays little attention to it.
\end{abstract}

Keywords: Auditory Evoked Potential, Auditory information processing, Task, Brain waves 聴覚誘発電位，聴覚情報処理，作業，脳波

\section{1.はじめに}

一般の建築環境下において、人間はその感覚器官を通して環境か ら様々な情報を受容している。感覚器官で受容された情報（感覚情 報）は、中枢神経系に送られて処理を受け、必要であれば判断・評 価がその情報に対して下される。また、それに基いて何らかの行動 が起こされたり、生体維持のための反応が末梢系に生じたりする。 このような、環境からの情報入力に対して生体に生ずる一連の反応 は、人間の中枢神経系を中心にした情報処理活動とその結果（出 力）とみなすことができる。その意味で、中枢神経系は生体内の感 覚情報処理システムと捉えることができる(図 1)。

建築環境と人間の関係を明らかにするためにある環境の条件に対 する生体の反応を捉える時には、感覚情報処理システムの出力（図 1）を測定することが一般的に行われる。この場合、感覚情報処理 システムとしての中枢神経系は、ブラックボックスとして扱われて いる。通常ブラックボックスとされるこの感覚情報処理システムを 何らかの手法で捉え、その㗢きを知ることができれば、従来からの 知見に加えて新たな切り口から環境と人間の関係に関する知見を蓄 えることが可能となると考えられる。

建築環境学の分野では、そのような立場から様々な環境からの入 力に対する中枢神経系の反応を捉える研究が、既に数多く行われて

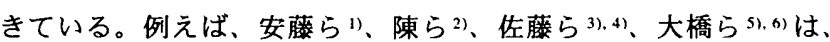
聴覚・視覚的な入力に対する中枢神経系の反応を脳波の形で捉え ている。これらの研究において測定対象とされている $\alpha$ 波等の脳 波は、生体へ入力された感覚情報に対する大脳の特定の情報処理 活動を捉えたものではなく、それをも含めた大脳の活動の総合的 な状態を捉えたものであり、その意味するところを解釈すること が難しい場合が多い。一方、安藤ら》、Ando ら ${ }^{81.91}$ は、聴覚情報の 入力に対する中枢神経系の反応を聴覚誘発電位の形で捉えている。 また明石ら ${ }^{10)}$ は、異なる照明条件下での作業への集中度を視覚に 関連する事象関連電位であるラムダ反応の安定度の形で捉えてい る。一般に誘発電位や事象関連電位は、様々な感覚情報入力に対

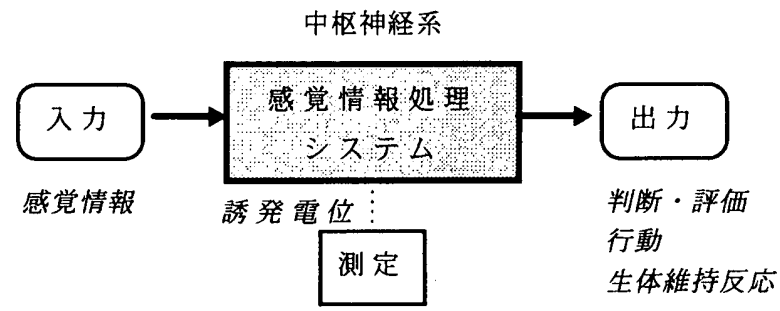

図 1: 感覚情報処理システムの概念図

\footnotetext{
* 東京大学大学院工学系研究科建築学尃攻 日本学術振興会 特別研究員 · 博士 (工学)

** 兵庫県都市住宅部住宅整備課 修士(工学)

*** 東京大学大学院工学系研究科建築学尃攻 助教授 $\cdot$ 工博

**** 東京理科大学工学部建築学科 教授.工博
}

JSPS Research Fellow, Dept. of Architecture, Grad. Sch. of Engineering, The University of Tokyo, Dr. Eng. Housing Development Div., Urban and Housing Dept., Hyogo Prefecture Government, M. Eng.

Assoc. Prof., Dept. of Architecture, Grad. Sch. of Engineering. The University of Tokyo, Dr. Eng.

Prof., Dept. of Architecture, Faculty of Engineering, Science University of Tokyo, Dr. Eng. 
する大腷の情報処理活動やある心的衰象の生起に基く大脳の情報処 理活動を捉えたものであり、認知過程の初期の部分に対応する生体 の反応"としてその意㧧するところは明らかである。

以上のように建築環境学における既往研究を概観すると、環境か らの感覚情報入力に対する中枢神経系の感覚情報処理を捉えること を目的とした場合、(1)信号発生の因果関係が明確であること、(2)大 脳の感覚情報処理・認知過程に関連した信号としてその意㙅が明ら かであるこよ、の理由により、測定対象の生体情報としては語発霓 位・事象関連電位が侹れていると判断できる。本研究では、中枢神 経系の生体反応として誘発電位を取り上げ、その測定・解析によっ て感覚情報処理の視点から環境と人間の関係に関して新たな知見を 得ることを試みた。

䛈発電位に関する研究は、生理学等の分野では古くから行われて おり、Picton ら ${ }^{12,131}$ 、Hillyard ${ }^{11} 、$ Blenner $5^{14)}$ の研究をはじめとし て、特に聴覚誇発電位・視覚誯発電位を利用した大脳の聴覚・視賞 情報処理システムの解明に関する多数の研究が行われて来ている 15)。しかし、これらの分野では大脳のメカニズムの解明が目的であ るため、その目的に対して都合のよい設定の実劉が行われる場合が 多い。例えばBlenner ら ${ }^{(4)}$ は、聴覚刺激として最大 $100 \mathrm{~dB}$ の強度の ものを使用しているが、そのような強度の聴覚刺激が生体へ入力さ れることは日常的な建築環境下では希である。このように、誇発電 位に関する生理学等の既往研究の成果は、そのまま建築環境制御の ための知見として応用することが難しいものが多い。従って、一般 的な建築懐境下での人間の感覚情報処理を捉え、それをもって環境 制御のための知見とするためには、生理学等の成果を基整として新 たに日常的に有り得る条件下で実験を行う必要性があると考えられ る。

一方、䛪発雪位測定を日常的な建築環境下での感覚情報入力に対 する生体反応を捉える手法として使う際の利点としては、判断・語 価等の感覚情報処理の出力に被験者を萁くことなくその反応を捉え ることができる（図 1)ことが第一に挙げられる。これは、被䋡者 の注意をある対象（感覚情報）に向けさせることなくその対象に対 する大脳の情報処理反応を捉えることができる、ということを意味 し、従来の感覚情報処理の出力を捉える手法では難しかったことを 可能とするものである。すなわち、生体側の心理的要因（注意等） と環境側の物理的要因の相互作用が感覚情報処理に及ぽす影劉を拯 るのに、㮇発電位測定の手法は適していると考えられる。

ところで、睘境から生体に入力される様々な感覚情報のうち、視 覚情報・聴覚情報の二者は、人間が空間を認識する上で重要な感覚 情報である。これらは、大腷において高次な処理を受けるという点 で穎似しているが、視覚情報が視線の向き・まぶたの懄きによって その処理対象が限定されるのに対し、聴覚情報は、通常の場合何の 制限もなく常に環境から生体に入力され続ける、という特徵を持 つ。すなわち、聴覚情報は、聴こうとして聴く場合はもちろん、聴 こうとしていない場合でも聴覚系から生体に受容され得る情報と言 える。しかも、聴こうとしていないのに聴いてしまう場面の方がよ り日常的であり、そのような場合の聴覚情報処理は聴こうとして聴 く場合の聴覚情報処理とは異なるものであることが予想される。

以上のような考察を総合した結果、本研究では、䁲境から生体に 入力される感覚情報として特に聴覚绩報に注目し、作業に焦中して
おり呈示される聴覚刺激に注意が向いていないような場面で、大脳 の情報処理の主要な対象となっていない聴覚情報が、人間によって どのように処理され知覚されるのかという点に関して、聴覚誘発電 位の測定・解析を通して知見を得ることを行った。

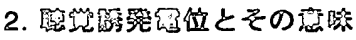

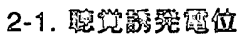

誇発電位とは、感覚受容器やその中枢への経路（感覚神経等）を 適当な刺激によって興琵させたときに、大脳に見られる刺激に対応

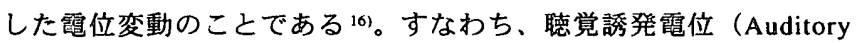
Evoked Potential, AEP）とは、耳を通して生体に受容された聴覚刺 激に対応して大脳に見られる電位変動のことであり、聴覚情報の入 力時点から $500 \mathrm{msec}$. 以内の時間帯に、頭皮上に置かれた電檽を通 して記録されるものである。AEPの初期成分（聴覚刺激入力時点か ら $10 \mathrm{msec}$. 以内) は聴性脳幹反応（Auditory Brain stem Response, $A B R$ ）と呼ばれ、感覚器から大脳皮質の一次聴覚野までの神経連鎖 による情報伝達時に生ずる電気的活動がその起源である。それに对 し、聴覚刺激の入力時点から $50 \mathrm{msec}$. 以降の長潜時の電位変動は、 頭頂部緩反応（Slow Vertex Response, SVR）とも呼ばれ、大脳皮質 の一次聴覚野以降の高次な聴覚情報処理に対応する。このような長 湻時の電位変動の起源は、大脳皮質部のニューロン群の同期した電 気的活動である15), 17), 18), 199, 20)。

AEPは、脳波よりもその振幅が小さいため、分析可能な電位変動 波形を得るためには、ABR で 2000 回、SVRで $50 \sim 60$ 回程度の、 聴覚请報の入力時点に同期させた加算平均が必要となる。また、 $A B R$ を含む短潜時〜中潜時の電位変動は、聴覚情報の物理的性質に 対応して変化し、SVRのような長潜時の電位変動は、聴覚请報の物 理的性質の影響も受けるが、心理的状態（注意の向き）の影翌をも 受ける”。本研究では、作業時の大脳における聴覚情報処理という、 入力される聴覚情報に人間の注意が向いていない場合の大脳の聴覚 情報処理に関して知見を得ることを行うため、また、少ない加算平 均回效で測定可能であり実験を遂行しやすく実験計画上の桑乾性も 高いという理由から、長潜時のAEPを測定対象とした。これ以後本 論文においては、単独でAEPの言茧が使われる場合、特に断りのな い場合には長潜時のもののみを意味している。

図 2(a)は、50 dBAのピンクノイズ（立ち上がり速度 $3 \mathrm{~dB} / \mathrm{msec}$ 、 緇続時間 $1 \mathrm{sec}$ 、暗騷音 $30 \mathrm{dBA}$ (ピンクノイズ呈示)）をスピーカ を通してランダムな間隔（1～15 sec.、1 sec.きざみ）で絽り返し 被頣者に呈示した際に、被匰者から記録した脳波（国際 10-20法の $\mathrm{Cz}$ 点より単極遵出）を聴覚刺激の立ち上がり部分と同期させて 60 回加算平均して得られた、AEP波形である。一方、図2(b)は、同じ く記録された脳波を聴覚刺激の立ち上がりとは同期させずに 60 回 加算平均して得られた波形である。これら二者を比皎すれば明らか なように、図2(a)には聴覚刺激の呈示時点から $500 \mathrm{msec}$. 以内に 3 つの明確なピークが見られる。これが、本研究で測定対象とする AEPである。これらのピークは、時間的に初期のものから N1，P2 N2 と一般的に呼ばれている。長潜時の AEPには、これら以外にも $50 \mathrm{msec}$. 付近にP1 と呼ばれるピークも存在するが、図 2(a)のよう に判別がつけがたいことが多いため、本研究では前述の3つのピー クを解析対象としている。なお、この図の横朝は、呈示した聴覚刺 

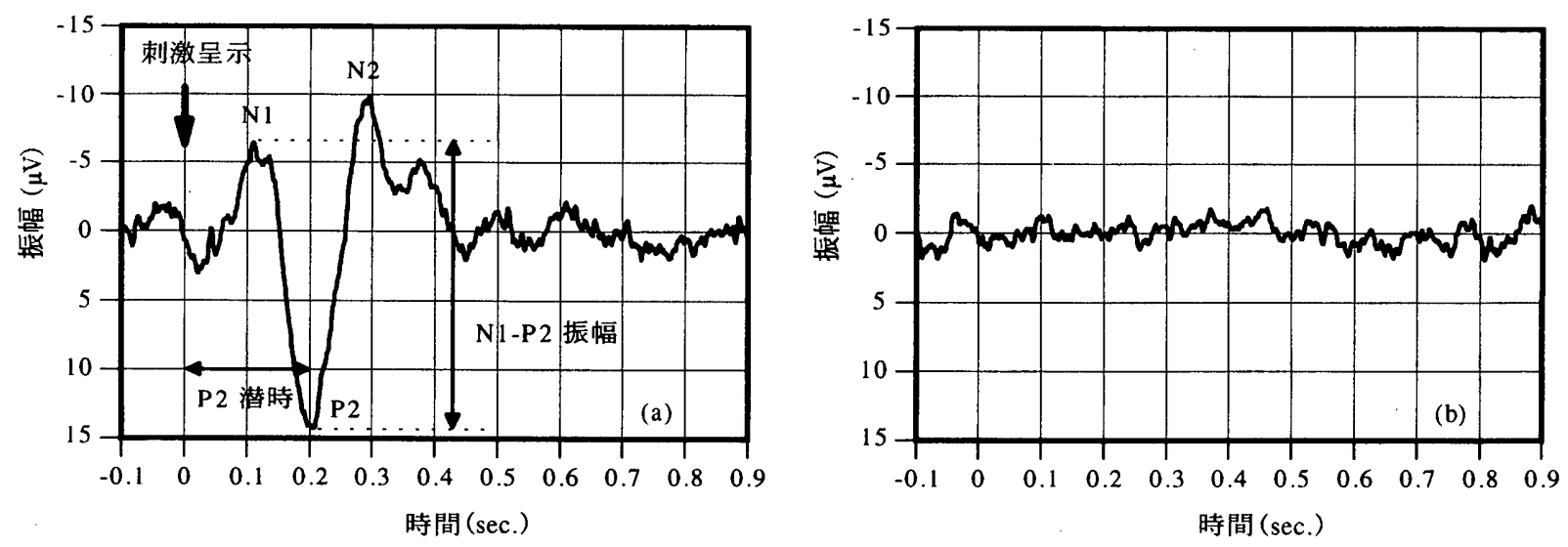

図 2: 聴覚誘発電位の例

激の立ち上がりからの時間を表わし、縦軸は、上方がAEPの負の振 幅値、下方が正の振幅值を表わしている。

AEPの解析にあたっては、各ピークの潜時（聴覚刺激呈示時から ピークまでの時間) と連続するニつのピーク間振幅值を、AEPの特 性を示す代表值として取り上げた。また、Picton ら ${ }^{(2), 13)}$ は、長潜時 のAEPの振幅は頭頂部付近で最大の值を示すとしている。本研究で は、これにならい頭頂（国際10-20法の Cz点）から測定される AEP を解析対象とした。

\section{2-2. 聴覚誘発電位の意味}

聴覚情報が耳から入力されると、その情報は幾つかの神経伝達を 経て一次聴覚野に至り、そこで初期の情報処理が行われる。AEPの ピークは、それ以後の高次な聴覚情報処理時に見られる同期した ニューロン群のシナプス後電位を測定したものである ${ }^{15)}$. 181。よっ て、そのピーク潜時は、そのピークを生じさせるニューロン群の活 動に至るまでの時間にあたり、大脳における聴覚情報の処理速度を 反映すると考えられる。また、同じAEPのピークに関する限りにお いては、ピーク間振幅は、それらのピークを生じさせるべく同期し て活動するニューロンの数によって決まると考えられるため15)、そ れらのピークが関連する聴覚情報処理反応の大きさ(情報処理反応 量）に対応する、と解釈することができる。本研究では、AEPの潜 時を情報処理速度、ピーク間振幅を情報処理反応量を反映するもの とみなし、それに基いて実験結果を解釈した。

\section{3. 実験 1}

\section{3-1. 目的}

作業時の大脳の聴覚情報処理に関して知見を得るために、呈示さ れる聴覚刺激とは無関係な作業を被験者に賦課した条件下で測定さ れるAEPを、そのような作業を賦課しない状態で聴覚刺激を呈示す る受動的あるいは積極的受聴態度の条件下で測定されるAEPと比較 することを目的として、実験を行った。よって、AEPを生じさせる 同期聴覚刺激は存在するが、それに対する聴取態度が異なる際に生 ずる AEP を比較することになる。

既往のAEPに関する研究によれば、AEPは聴覚刺激の音圧レべ

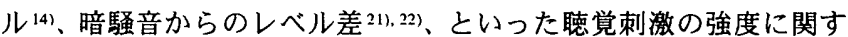
る物理的性質の影響を受ける。また、実際の音環境の場面を考えて
みても、存在する聴覚情報の強度は様々であり、その強度によっ て、作業中の人に無視され得る聴覚情報と作業をしていても十分に 知覚される聴覚情報の両者が存在することが、予測される。よつ て、この実験では、実験要因のひとつとして聴覚刺激の強度を取り 上けた。

\section{3-2. 方法}

実験は、1993 年 12 月から 1994 年 1 月にかけて、東京大学工学部 建築学科の半無響室内で行った。聴覚刺激としてピンクノイズ（立 ち上がり速度 $3 \mathrm{~dB} / \mathrm{msec}$ 、、継続時間 $1.6 \mathrm{sec}$.) を使用し、被験者の 正面前方 $2.5 \mathrm{~m}$ の位置にあるスピーカを通して、以下に示す 3 種類 の聴取条件下にある被験者に聴覚刺激を呈示する実娩を行った。実 験中の被験者の脳波は、8 mm径の $\mathrm{Ag} / \mathrm{AgCl}$ 電極を用いて国際 10-20 法の Cz点から耳染A1を基準電極として単極導出し、生体アンプ（日 本光電製 MME-3116）でフィルタ（1.6 Hz〜100 Hz）をかけ增幅 した後、データレコーダに記録した（図 3)。ここで、ピンクノイズ を聴覚刺激に使用したのは、どの被験者にも共通に無意味な聴賞刺 激だと考えられるからである。

実験要因の一つは聴覚刺激の強度であり、受聴点音圧レベルで $35,40,50,60,70,80 \mathrm{dBA}$ の 6 水準を設定した。なお、実験中は 30 $\mathrm{dBA}$ (受聴点) のピンクノイズを暗騷音として呈示し続けた。

実験要因の二つ目は聴取条件であり、以下の 3 水準を設定した。 [条件 A] 被験者に閉眼安静の状態を指示し、呈示される聴覚刺激 を㯖くように教示した。

[条件 B］被験者に閉眼を指示したが、その状態を保ったまま、繰 り返し呈示される聴覚刺激のすべてに対して、呈示㨁後にうるささ （聴覚刺激の気になる度合）の評価を手元のキーボードから 5 段階 で入力するように教示した。なお、被験者にはあらかじめ入力する キ一の位置を覚えさせ、閉眼の状態でも入力が可能であることを確 認した上で実験を行った。

[条件 C] 被験者に閉眼を指示したが、絽り返し呈示される聴覚刺 激を気にしないようにしながら、あらかじめ記憶させた 10 桁の数 字を、あらかじめ記憶させた $0.5 \mathrm{sec}$. の間隔で、この条件での実験 時間中休みなく繰り返し正確に手元のキーボードから入力し続ける ように教示した。10析の数字は人差し指・中指・薬指の 3 本の指で 閉眼の状態でも簡単に入力できる数字であり（図4)、この条件のも 


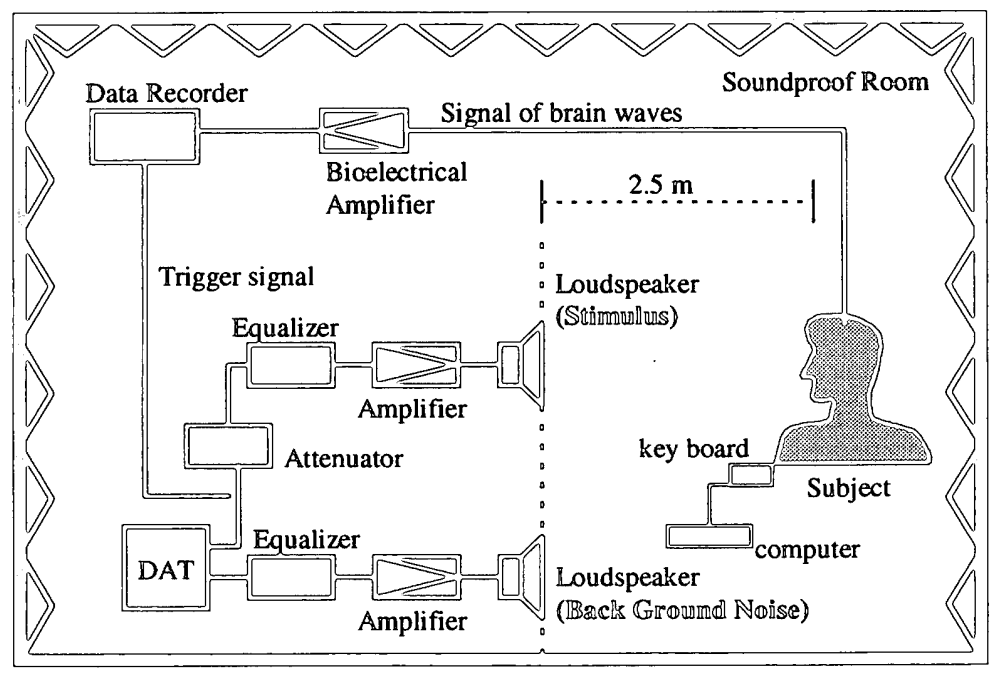

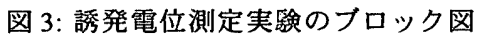

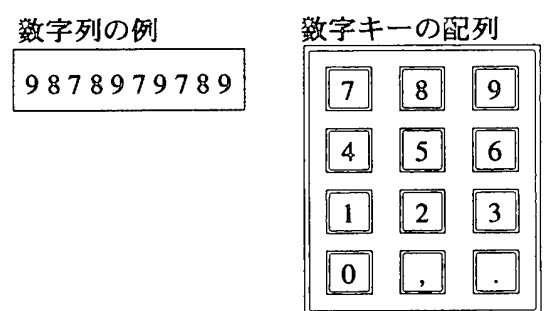

図 4: 記嬑させた数字列の例とキーボード配列

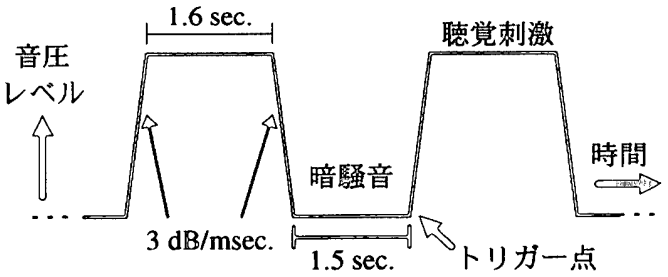

図 5: 聴覚刺激の呈示パターン（実験 1）

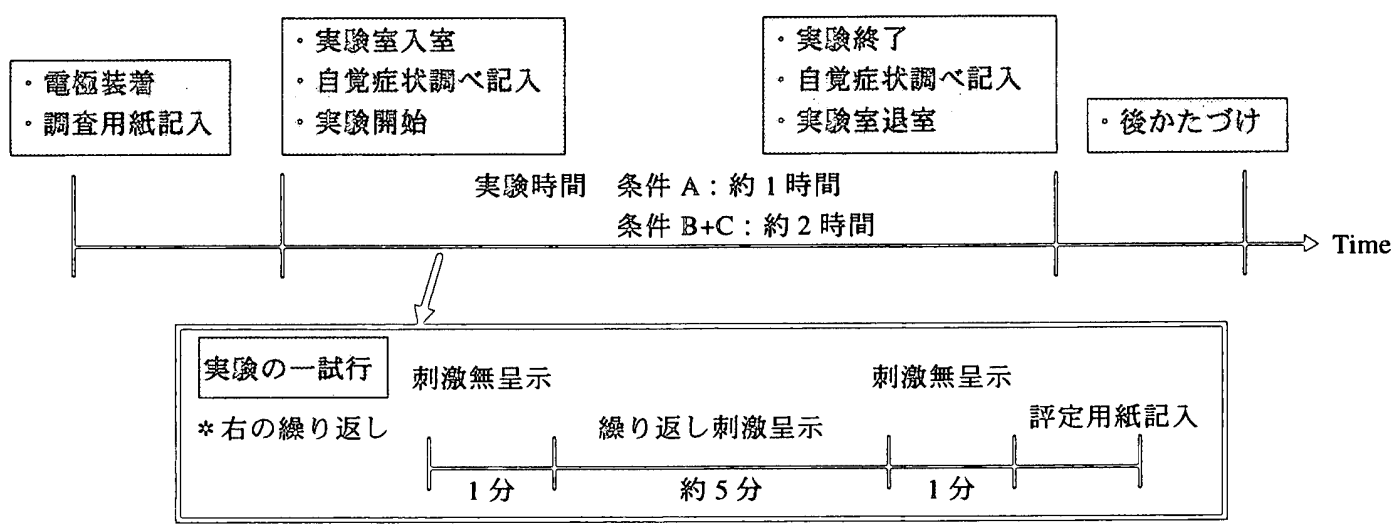

図 6: 実験 1のタイムスケジュール

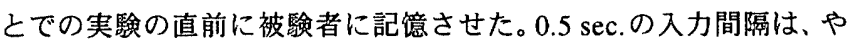
はりこの㶻件のもとでの実毁の直前に、刺激呈示用のスピーカから $1 \mathrm{kHz}$ 純音（䌡続時間 $0.1 \mathrm{sec}$.) を $0.5 \mathrm{sec}$. 間隔で䌈り返し呈示する ことによって記億させた。この聴取条件では、入力作業のタイミン グと㯖覚刺激呈示のタイミングの間には関連がない。

条件Cは、記憶した数字列の正確な入力作業に被稳者を焦中させ

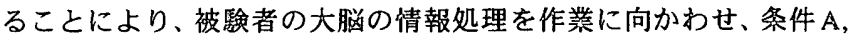
Bよりも聴覚刺激に対する情報処理の㑑先度が低くなることを意図 した条件設定である。また、条件 A では被距者は聴覚刺澈を受動的 に聴くだけであるが、条件Bでは聴覚刺激に対して語価を下す過程 が付加されている。条件 B は、被匼者がより䅡極的に聴覚刺激を聴 くことを意図した条件設定である。また、全聴取条件において閉眼 を指示したが、これは、感覚情報として環境から入力される情報を 聴覚情報だけに限ることを意図したためである。

実虽の一試行においては、ある一つの聴取条件下で、同じ音圧レ ベルの聴覚刺激を一定の呈示間隔 $(1.5 \mathrm{sec}$ ) で 70 回繰り返して被

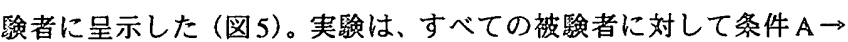
条件 $\mathrm{B} \rightarrow$ 条件 $\mathrm{C}$ の順に行われた。但し、等件 $\mathrm{B}, \mathrm{C}$ での実絟は、条
件 A での実駼とは別の日に休䕀をはさんで連続して行われた。ま た、各聴取条件下で、呈示する聴覚刺激の音圧レベルの順序が上昇 系列 $(35,40,50,60,70,80 \mathrm{dBA}$ の順に呈示) の群と下降系列 (80, $70,60,50,40,35 \mathrm{dBA}$ の順に呈示）の群とに分けて、荚験を計画 した。

被駼者は、男性 8 名・女性 3 名の計 11 名であり、各被歌者は呈示 音圧レベル（6水準）と聴取条件（3 水準）の組合わせからできる 計 18 水準の試行のすべてを経験した。実虽のタイムスケジュール は、図6に示すとおりである。

3-3. 嘴累

データレコーダに記録した脳波を、シグナルアナライザー (HP35670A、A/D変換のサンプリング周波效 : $1024 \mathrm{~Hz}$ 、サンプリ ング点效 : 1024 点住) を用いて、聴覚刺激の立ち上がりと同期させ て原則的に 64 回加算平均して AEP 波形を得た。但し、最初の 4 回 と、明らかにアーティファクトが混入したと思われる振幅変動をし たものは、加算平均から除外している。その結果、全被監者から各 聴取条件においてAEP波形が得られた。得られたAEP波形から、N1, P2, N2 の潜時とN1-P2, P2-N2のピーク間振幅を読み取った。但し、 

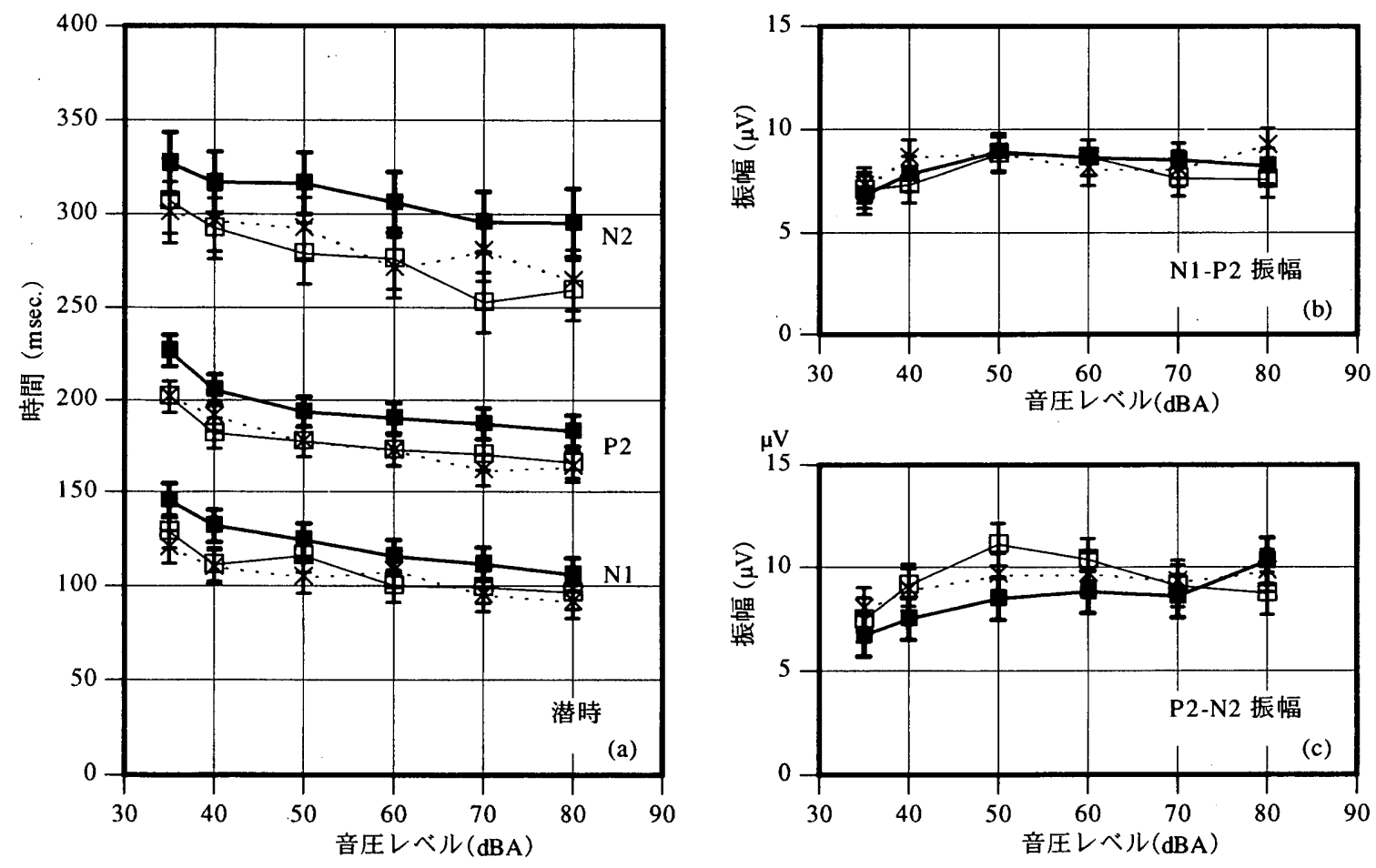

$\square$ Condition (A) $\cdot \times \cdot$ Condition (B) $\rightarrow-$ Condition (C)

図 7: 実験 1 の結果（各点は被験者平均值、各誤差線は $95 \%$ 信頼区間を表わす。）

ノイズに埋もれてピークが読みとれない場合、そのピークが関倸す る潜時・ピーク間振幅の值は欠測データとした。

読み取った潜時・ピーク間振幅值をもとに、各潜時・各ピーク間 振幅について、呈示音圧レベル・聴取条件を要因として二元配置分 散分析を行った。

その結果、各潜時について、呈示音圷レベルの主効果（N1：F (5, $160)=20.49, \mathrm{p}<0.001 ; \mathrm{P} 2: \mathrm{F}(5,170)=25.94, \mathrm{p}<0.001 ; \mathrm{N} 2: \mathrm{F}(5$, $167)=8.18, \mathrm{p}<0.001)$ と、聴取条件の主効果 $(\mathrm{N} 1: \mathrm{F}(2,160)=$ $24.96, \mathrm{p}<0.001 ; \mathrm{P} 2: \mathrm{F}(2,170)=30.35, \mathrm{p}<0.001 ; \mathrm{N} 2: \mathrm{F}(2,167)=$ $20.52, \mathrm{p}<0.001)$ が有意であり、それらの間に交互作用は見られな かった。これらの結果は、(1)各潜時が聴覚刺激の音圧レベルが小さ い時（35 dBA）に長く、增大するに従って短くなること、(2)特に条 件Cでは呈示音圧レベルに関係なく他の条件に比べて潜時が長くな ること、を示している(図7(a))。

N1-P2振幅に関しては、音圧レベルの主効果のみが有意であり $(\mathrm{F}$ $(5,160)=2.72, p<0.05)$ 、聴取条件の主効果及び音圧レベルと聴 取条件の交互作用に有意性は見られなかった。このことは、(1)聴取 条件にかかわらず $50 \mathrm{dBA}$ 以下の領域で呈示音圧レベルの増大に 伴って振幅が大きくなり、その後安定する傾向にあること、(2)各聴 取条件間でN1-P2 振幅值に明確な差がないこと、を示している（図 $7(b))$ 。

P2-N2 振幅に関しては、音圧レベルの主効果 $(\mathrm{F}(5,167)=6.14$, $\mathrm{p}<0.001)$ と、聴取条件の主効果 $(\mathrm{F}(2,167)=4.59, \mathrm{p}<0.05)$ が 有意であり、それらの間に交互作用は見られなかった。この結果 は、(1) P2-N2 振幅は 50dBA 付近までは聴覚刺激の音圧レベルの增 大に伴って大きくなりその後安定する傾向にあること、(2)条件 Cで
は他の聴取条件よりも振幅が小さくなること、を示している（図 $7(\mathrm{c})$ )。

\section{3-4. 考察}

実験 1 の潜時に関する結果は、(1)呈示される聴覚情報を聴こうと している/いないにかかわらず、より大きい音の方が速く処理され ること、(2)条件 A，B のように大脳において聴覚情報処理が優先さ れるような状況では、情報処理の速度に差がなく同様の処理がなさ れること、(3)条件 Cのように被験者が作業遂行に集中しており大脳 において聴覚情報処理が非優先の状況下では、情報処理の速度が遅 くなること、を示していると解釈できる。

振幅に関する結果では、聴取条件 A, B でのN1-P2 振幅・P2-N2 振 幅において、 $50 \mathrm{dBA}$ を越える音圧レベルの聴覚刺激に対して振幅 の安定化の傾向が見られた。これは、聴覚情報処理時に同期する ニューロンの数が飽和した結果と解粕できる。また、両振幅とも、 条件 A, B 間で振幅值に差が見られなかった。AEPの振幅を大脳の 情報処理反応量に対応すると考えると、これらの結果は、(1)条件 A, B のように大脳において聴覚情報処理が優先されるような状況で は、入力される聴覚情報の強度の增大に伴って大脳の情報処理反応 量も增大すること、(2) $50 \mathrm{dBA}$ 以上の強さを持った聴覚情報に対し ては、一様に十分な反応量を持った聴覚情報処理が大脳において行 われるようになること、を表わしていると解釈できる。

一方、条件 Cの振幅に関する結果では、N1-P2 振幅・P2-N2 振幅 ともに聴覚刺激の音圧レベルの增大に伴って振幅值が大きくなると いう、条件 A, B と同様な傾向が見られた。また、N1-P2 振幅では条 件 A, Bで得られた振幅值と変わらないが、P2-N2振幅において条件 $\mathrm{A}, \mathrm{B}$ と比べて振幅值が小さくなる傾向が見られ、この傾向は 40,50 , 
$60 \mathrm{dBA}$ 付近において顥都となることが明らかとなった。このこと は、(1)聴覚情報の入力から時間が経過しより高次な情報処理過程に 進んだ段階において、被臨者が作業遂行に集中し大腷で聴覚情報処 理が非侹先の状況下では、40,50,60 dBA 程度の聴覚情報に対して は相対的に小さな聴覚情報処理反応しか生じないこと、(2)それより も大きい音圧レベルの聴覚刺激に対しては一様に十分な反応且を 持った聴覚情報処理が生ずること、を示している。この結果は、40， 50,60 dBAの聴覚请報は大脳がそれらの処理を㖊先していない場合 により小さな知覚反応の対象にしかならないが、それより大きい聴 覚情報は大脳が何を侹先して绩報処理をしているかにかかわらず一 样に大きく知覚され得る、と解䣋できる。また、 $35 \mathrm{dBA}$ の聴賞刺 激に対しても聴取条件間で P2-N2 振福に差がない傾向が見られる が、このことは、レベル差にして $5 \mathrm{~dB}$ 程度の弱い聴覚情報は聴取 条件によらず一様に小さく知覚されることを意味する、と解积でき る。

以上のように考察を行ったが、実戨 1 で設定した实倹要因では聴 覚刺激の呈示間隔を一定としたため、条件 A, B では次に呈示され る刺激の立ち上がりが予測できるが、条件Cでは刺激の呈示と無䦎 係なタイミングで作業が被敛者に賦㹎されているため、次の刺激の 立ち上がりが予測できない、という事態が生じた。 Karlin ${ }^{23)}$ は刺激 の入力の予期が可能であることが䛦発電位の振幅の增強に影非を及 ぼすとしており、従って実龉 1 の結果には刺激入力の予期の可否が 影響を及ほした可能性がある。そこで、この点を検証し実跧 1 の結 果の再現性を検討することを目的として、新たな実蜍を計画した。

\section{4. 实臨 2}

4-1. 目的

実鈳 1 の結果を検証すると同時に、より一般の建築環境であり得 る聴取条件下での聴覚情報処理、特に入力される聴覚情報に注意を 向けることなく作業をするというような現実の場面で、日常的に生 体によって行われている聴覚情報処理に関して知見を得るために、 ランダムな間隔で呈示される聴賞刺激を用いて、受動的受㯖（閉眼 及び開眼) 条件及び暗算作業に集中し聴賞请報に注意が向かない聴 取条件のもとで、AEP を測定する実鈳を行った。

\section{4-2. 访济}

実歌は、1994年 7 月から 8 月にかけて、賁京大学工学部建築学科

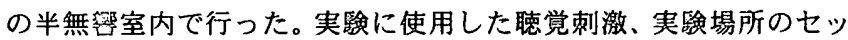
ティング（図3）、AEP測定・記録の手続きは、実験 1 と同様である。

実験要因の一つは聴覚刺激の強度であり、受聴点音圧レベルで $33,40,50,70 \mathrm{dBA}$ の 4 水準を設定した。なお、実験中は $30 \mathrm{dBA}($ 受 聴点）のピンクノイズを暗騒音として呈示し続けた。

実毁要因の二つ目は聴取条件であり、以下の 3 水準を設定した。 [条件 X] 被験者に閍眼安静の状態を指示し、呈示される聴覚刺激 を聴くように教示した。

[条件 Y] 被験者に開眼の状態を指示し、被鳘者の前面約 $60 \mathrm{~cm}$ の 位置にあるノート型コンピュータの液晶ディスプレイ（白黒）に表 示されるランダムな動きをする線の先端を、頭部を動かさないよう にしながら視線で追うように教示した。聴覚刺激に対する聴取態度 に関する教示は、行わなかった。

[条件Z] 被嚠者に開眼の状熊を指示し、絽り返し呈示される缌覚刺
激を気にしないようにしながら、被㷂者前面のノート型コンピュー 夕の液晶ディスプレイ上に休みなく出題される加減算問題の、結果 の正誤判別作業を行わせた。この作業の進行は、聴覚刺激の呈示夕 イミングとは無関係であり、被敛者には浬題になるべくすばやく正 確に答えるように教示した。

条件Y, Zにおいて、ノート型コンピュータは被験者の前面やや下 側の机上（被験者の座っている椅子と一体型の簡易机）に置かれて おり、その液晶ディスプレイが被験者正面の刺激呈示用スピーカを 遮ることはなかった。また、受聴位置での音場の条件をそろえるた め、条件Xにおいてもノート型コンピュータは同じ位置に同じ状態 で設置した。条件 Zの暗算作業諰題は、ディスプレイの決まった位 置にまず 1 秒間加減算の式が表示され、式が消えた後それに対する 解答（正しい答えが表示される確率 $50 \%$ ）が以前に式が表示され ていたのと同じ場所に表示され、その正誤判断をあらかじめ決めて おいた正・誤・判別不能に対态したキーから入力する、という作業 である。その際に、解答は正誤判別の結果が入力されるまで表示さ れ続け、結果が入力されるとすぐに次の問題に移る、という形で作 業は休みなく被験者に賦課され続けた。なお、キーは人差し指・中 指・蔡指で簡単に入力できるものであり、作業中に被臥者は視線を 画面からそらさずに結果の入力が可能であった。

条件Xは、環境から生体に入力される感覚情報を聴覚情報のみに 限定することを意図した受動的聴取条件である。条件Yは、聴覚情 報に加えて単純かつ定常的で無閏係な視覚情報 (それに関連した判 断・俨価等の情報処理が伴わない) の入力が付加された、受動的聴 取条件である。条件 Zは、休みなく賦浬される暗算作業に集中する ことにより、大脳の情報処理が作業傮先の状態となるようにし、条 件 X,Yよりも聴覚情報に対する処理の传先度が低くなることを意 図した聴取条件である。

実臨の一試行においては、ある一つの聴取条件下で、同じ音圧レ ベルの聴覚刺激を 1 〜 $15 \mathrm{sec}$. の間でランダムな呈示間隔（ただし、 $1 \mathrm{sec}$.きざみ）で70回繰り返して被験者に呈示した（図8）。実驗 は、呈示音圧レベル（4 水準）と聴取条件（3 水準）の組合せでで きる計 12 水準の試行を、順序勃果と系列位置効果を除去すべくう テン方格法で計画した実鈳䫁序で、12名の被験者（男性 10 名・女 性 2名）に対して行った。よって、被験者ごとに実験順序は異なり、

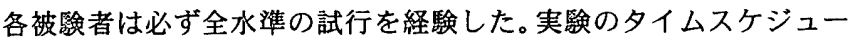
ルは、図 9 に示すとおりである。

4-3. 橴黑

実鈳 1 と同様に、全被験者から各聴取条件においてAEPが得られ た。AEPの各潜時・各ピーク間振幅值を得た後、呈示音圧レベルと 聴取条件を要因として二元配置分散分析を行った。ただし、AEPを

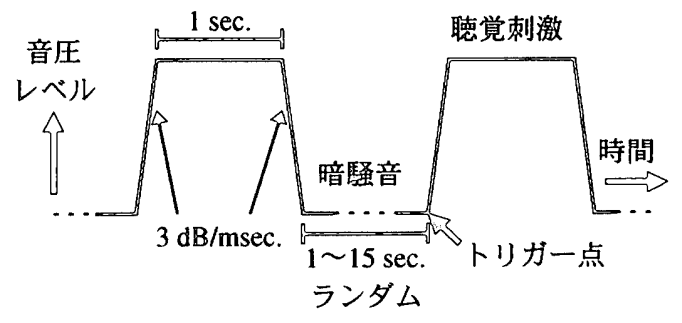

図 8: 聴賞刺激の呈示パターン（実鳘 2) 
*各被験者とも、実験は 4 試行ずつ 3 回に分けて行った。以下のスケジュールはそのうちの 1 回あたりのものである。

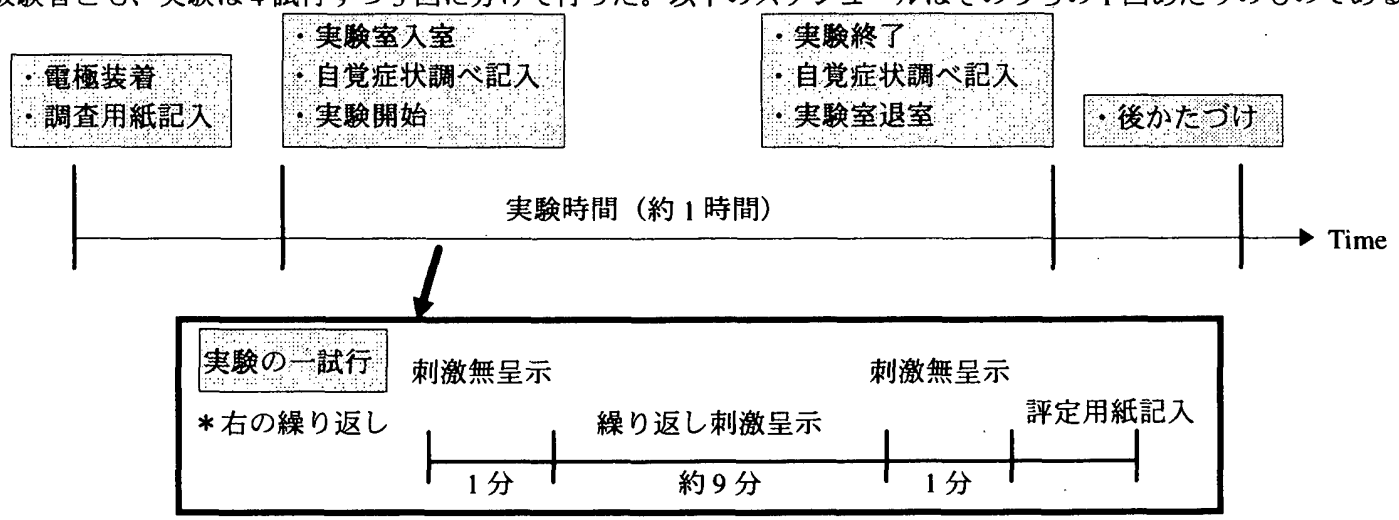

図 9: 実験 2 のタイムスケジュール
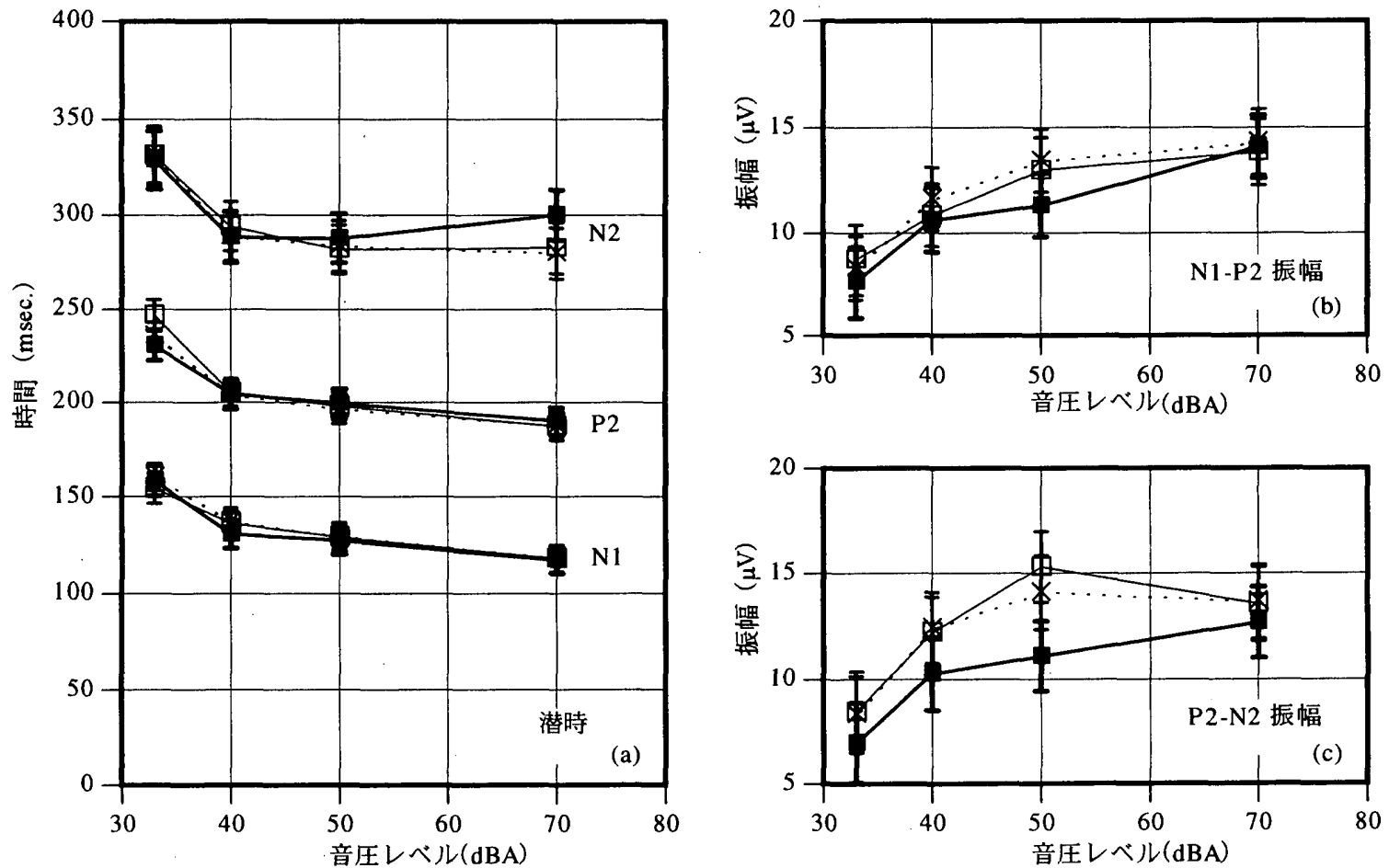

$\square \quad$ Condition $(X) \quad \cdot \times \cdot$ Condition $(Y)$

$\rightarrow$ Condition $(\mathrm{Z})$

図 10: 実験 2 の結果（各点は被験者平均值、各誤差線は $95 \%$ 信頼区間を表わす。）

得るための加算平均回数は原則的に 60 回とした。

その結果、各潜時について、音圧レベルの主効果 $(\mathrm{N} 1: \mathrm{F}(3,111)$ $=61.52, \mathrm{p}<0.001 ; \mathrm{P} 2: \mathrm{F}(3,113)=87.0, \mathrm{p}<0.001 ; \mathrm{N} 2: \mathrm{F}(3,109)=$ $25.88, \mathrm{p}<0.001)$ のみが有意であり、聴取条件の主効果と音圧レべ ル・聴取条件の間の交互作用は見られなかった。このことは、(1)聴 覚刺激の音圧レベルが $33 \mathrm{dBA}$ の条件で潜時が長く、呈示音圧レペ ルの增大に伴って潜時が短くなること、(2)聴取条件間で潜時に違い がないこと、を示している(図 10(a))。

$\mathrm{N} 1$-P2 振幅に関しては、音圧レベルの主効果 $(\mathrm{F}(3,110)=28.85$, $\mathrm{p}<0.001 ）$ のみが有意であり、聴取条件の主効果や音圧レベル・聴 取条件の間の交互作用は見られなかった。この結果は、(1)N1-P2 振
幅が聴覚刺激の音圧レベルの増大に伴って大きくなること、(2)聴取 条件間で振幅に差がないこと、を示している（図 10(b)）。

P2-N2 振幅に関しては、音圧レベルの主効果 $(\mathrm{F}(3,109)=23.38$, $\mathrm{p}<0.001)$ と聴取条件の主効果 $(\mathrm{F}(2,109)=6.77, \mathrm{p}<0.01)$ が有 意であるが、それらの間に交互作用は見られない、という結果が得 られた。この結果は、(1)聴覚刺激の音圧レベルの增大に伴って P2N2 振幅が増大すること、(2)条件 Zにおいて他の 2 条件よりも振幅 が小さくなること、を示している(図 10(c))。

\section{4-4. 考察}

実験 2 の潜時に関する結果は、聴取条件によらず呈示音圧レベル の増大に伴って大脳における聴覚情報処理の速度が速くなることを 


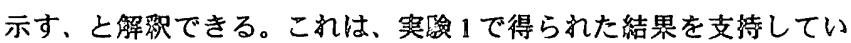
る。しかし、実駼 2 の結果では、実壆 1 の結果と異なり聴取祭件間 で潛時に差が見られなかった。このことは、聴賞情報処理が大脳に おいて腥先されている場合には、そうでない場合に比べて聴覚情報 処理の速度が速くなるとした、実験 1 の考察と矛盾する。従って、 実叙 1 の考察の最後に述へたように、実臨 1 の潜時に関する結果に は、聴覚情報の入力の予期の可否が影哣を及ぽした可能性が考えら れる。ここで、実䟻 1 と 2 の各ピーク潜時の値を比皎してみると、 実跧 2 の各ピーク潜時の平均值は実監 1 の条件凹の值に近い。また、 実崄 2 の設定では聴覚刺激の呈示間隔はランダムであるので、聴取 条件にかかわらず被驗者は聴覚刺激の立ち上がりを予測できない。 一方、実鈳 1 では、前述したように条件Cのみにおいて被験者は聴 覚刺激の立ち上がりを予測できなかった。これらのことを考え合わ せると、実馈 1 の潜時に見られた聴取条件間の差は、聴覚情報の入 力が予期できるか否かが聴覚请報処理の速度に影郆を及ぼした結果 であり、ある聴覚刺澈の出現が予期可能な場合ほどスムーズな聴覚 情報処理が大脳において行われることを意哧する、と解䣋する方が よいと考えられる。Karlin ${ }^{23)}$ の仮説は、刺激の入力の予期の可否が 誘発電位の振幅に影哆を及ぽすとするものであるが、本研究の結果 は聴覚䛈発電位の潜時に関しても影劉が出ることを示唆している。

振幅に関する結果からは、実铯 1 と同様に、聴取条件 X,Yでの N1-P2 振幅・P2-N2 振幅において、(1)ピーク間振幅が聴覚刺澈の音 圧レベルの増大に伴って大きくなること、(2)その現象が特に 50 dBA以下で影著であること、(3)それを超える強さの聴覚刺激に対し ては、聴覚情報処理時に同期して活動するニューロンの数が飽和す る傾向にあること、が示された。また、両振幅とも、条件 X, Y 間 で振幅值に差が見られなかった。これらの結果は、大脳において聴 覚情報処理が侹先される状況にある聴取条件Xに限らず、判断・語 価等の高次な情報処理が伴わない視覚情報処理が存在する条件Yに おいても同樣に、聴覚绩報処理の反応量が㯖覚情報の強度の増大に 伴って增大し、 $50 \mathrm{dBA}$ を越える強さの聴賞情報に対しては十分な 情報処理が大脳において行われるようになることを意哧している。

一方、条件 Zの振幅に関する結褁では、N1-P2 振幅・P2-N2 振幅 ともに聴賞刺激の音圧レベルの増大に伴って振幅値が大きくなると いう、条件 X,Yと同様な傾向が見られた。また、N1-P2 振幅では条 件X,Yで得られた振幅値と変わらないが、P2-N2振幅において条件 $X, Y$ と比べて振幅值が小さくなる傾向が見られ、この傾向は 50 $\mathrm{dBA}$ の呈示音圧レベル条件で顕著であった。また、70 dBAでは聴 取条件間に振幅の差が見られなかった。これらの結果は、聴覚情報 の入力から時間が経過したより高次な情報処理過程においては、(1) 聴覚情報処理が大腷で传先されていない場合に、50 dBA 以下の比 皎的小さな聴覚刺激はより小さな情報処理反応しか引き起こさない こと、(2) $70 \mathrm{dBA}$ の比皎的大きな聴覚刺激は聴覚情報処理が俨先さ れている場合と同等の十分な処理反応を引き起こすこと、を示して いる。すなわち、大腷において聴覚情報処理以外が侹先されている ときには、 $50 \mathrm{dBA}$ 以下の音は実際の音よりも小さな知覚反応の对 象としか見なされないことが示唆される。

これらの振幅に関する結果は赛験 1 の結果と矛盾せず、大脳の聴 覚情報処理の反底量は大脳において聴覚情報処理が戝先されている か否かの影㽬を受ける、と結論できる。Kramer ら ${ }^{24)}$ は、入力され
る聴賞刺澈とは無関铄な作鄴の存在が、N100（本論文のN1にあた る)、N200（本論文のN2にあたる）、P300（本論文では扱っていな い）の振幅の減少に影憎を及ぼすとし、それを大脳の有限な処理能 力の配分による結果としている。本研究で行った実跧とは課題・刺 激等が異なるため直接の比較はできないが、本研究の結界はその考 察を支持するものであると同時に、そのような勃果が呈示される刺 激の強度によって異なる可能性をも示唆している。

\section{5. きと的}

聴喾䛪発雪位の測定・解析の手法を用いて、作業時の人間の大脳 における聴党情報処理に関して知見を得るべく二つの実鈳を行っ た。その結果、(1)聴覚情報処理の速度と反応量は入力される聴覚情 報の強度に影倣を受けること、(2)聴覚情報処理の速度は環境から生 体に情報が入力されるタイミングの予測の可否の影鄕を受け、処理 の反応䖧は大脳において聴賞情報処理が戝先されているか否かの影 贸を受けること、が示された。すなわち、(1)大脳の聴覚情報処理速 度は、入力される聴覚情報の強度が大きくその入力が予期可能なほ ど速くなり、聴覚情報の強度が大きく聴覚情報処理が缏先されてい るほど、処理反応昜は大きくなること、(2)乵㖆を伴う作業に集中し ている等で大媨において聴覚情報処理が梴先されていない場合で も、70 dBA 程度の大きさの聴覚情報は经先されている場合と同等 に十分大きな処理反応を引き起こすこと、が示された。

これらの結果は、実験室内での限られた実験条件に対して得られ たものに過ぎないが、例えばある作業環境で判断を伴う作業に焦中 している作業者に対して聴覚的に情報伝逆を行う場面において、確 実な情報伝達を実現するのに適切な聴覚情報の強度の存在を示唆す るものと考えられる。

また、各実験の考察では触れなかったが、実験 1 では $30 \mathrm{dBA} の$ 暗驟音レペルに対して $35 \mathrm{dBA}$ の聴覚刺激が呈示された場合、実跧 2 では $30 \mathrm{dBA}$ の暗騒音レベルに対して $33 \mathrm{dBA}$ の聴覚刺澈が呈示さ れた場合にも、聴覚情報処理が檪先されていない各々の聴取条件下 （条件 C及びZ）で、ノイズとは分離して判別可能な AEPが測定さ れた。AEPの存在は、大脳において聴覚情報処理が行われているこ との証明である。これらの結果は、わずかにレベル差 $3 \mathrm{~dB}$ 程度の 弱い聴覚刺澈でさえも、作業に集中してそれに関する情報処理に終 始しているはずの大脳において、無視されずに何らかの情報処理を 受けていることを示している。このことは逆に、聴覚情報処理が並 行して行われているが故に、レベル差 $3 \mathrm{~dB}$ の聴覚刺激でも、本来 伐先させているべきの作業に関連した大腷の情報処理に対して、干 渉等の影暗を及ぼす可能性があることを示唆する。

本論文では、䛪発電位測定・解析の手法を用いることによって、 感覚情報処理の視点から環境と人間の関係を捉えることを行った。 ここで行ったように、生体反応をその信号発生のメカニズムの観点 から解猺することによって、制御対象となる環境と人間の関係を解 明することが可能となると考えられる。今後もこのような視点から

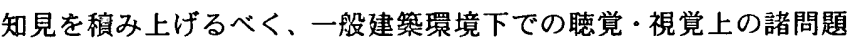
に関して研究を進める予定である。

なお、本研究は文部省科学研究費補助金（特別研究員奖励費）に よる研究の成果である。 
注

AEPを得るための加算平均は、シグナルアナライザーでA/D变換した上で行っ た。ここで言うサンブリング点数とは加算平均に利用した 1 データのデー夕長の ことである。1024 Hzのサンブリング周波数であるから $0.98 \mathrm{msec}$.きざみに離散 化された $1 \mathrm{sec}$. 長の脳波を必要回数加算平均して、AEP 波形を得たことになる。

\section{本論文に関する既発表論文}

1) 秋田剛，平手小太郎，安岡正人：德取状態による聴賞誘発電位の变化に関 する研究, 日本音響学会講演論文集，I，pp. 367-368, 1994.3

2) 秋田剛、滕井利幸，平手小太郎，安岡正人: 㯖觉㮩発電位測定による音環境

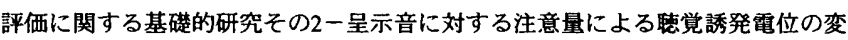
化一, 日本建築学会大会学術丵演梗啭集, D, pp. 1997-1998, 1994 3) 秋田剛, 藤井利幸, 平手小太郎, 安岡正人: 開眼時・作業負荷時の㯖賞誘発電 位測定,日本音響学会講演論文集, I , pp. 441-442, 1994.10

4) Akita, T., Hirate, K., and Yasuoka, M.: The Effect of Attention on Perception of Sound from the Viewpoint of Auditory Evoked Potential, Proc. of INTER-NOISE 95, II , pp. 839-842, 1995

\section{参考文献}

1) 安藤四一, 陳姛尭: On the Analysis of Autocorrelation Function of $\alpha$-Waves on the Left and Right Cerebral Hemispheres in Relation to the Delay Time of Single Sound Reflection, 日本建築学会計画系論文集, No. 488, pp. 67-73, 1996.10

2) 陳烟克, 安藤四一: On the Relationship between the Autocorrelation Function of the $\alpha$-Waves on the Left and Right Hemispheres and Subjective Preference for the Reverberation Time of Music Sound Field, 日本建築学会計画系論文集, No. 489, pp. 73-80, 1996.11

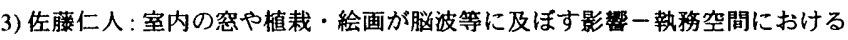
視器境の生理心理的影響に関する研究一, 日本建築学会計画系論文集, No. 461, pp. 87-95, 1994.7

4) 佐藤仁人, 当摩昭子, 中山和美, 高橋誠: 執務空間における照度の生理・心理 的影響，照明学会誌，Vol. 80 No. 5, pp. 23-30, 1996

5) Oohashi, T., Nishina, E., Kawai, N., Fuwamoto, Y., and Imai, H.: High frequency sounds above the audible range affect brain electric activity and sound perception, Audio Engineering Society 91 st Convention (New York) Preprint 3207, pp. 1-25, 1991

6) 大橋力: 放送教材の改善のための音警効果に関する研究開発 (2), 放送教育開 発センター研究報告第 44 号, 1992

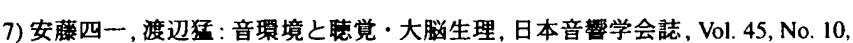
pp. 794-799, 1989

8) Ando, Y., Kang, S. H., and Nagamatsu, H.: On the auditory-evoked potential in relation to the IACC of sound field, J. Acoust. Soc. Jpn. (E), 8, pp. 183-190, 1987

9) Ando, Y., Kang, S. H., and Morita, K.: On the relationship between auditory-evoked potential and subjective preference for sound field, J. Acoust. Soc. Jpn. (E), 8, pp. 197 204, 1987

10) 明石行生, 金谷末子, 八木昭弘 : 作業者の集中度と周辺照度／作業面照度の 比との関係, 照明学会誌, Vol. 80, No. 8A, pp. 540-549, 1996

11) Hillyard, S. A.: Electrophysiology of human selective attention, Trends in Neurosciences, 8, pp. 400-405, 1985

12) Picton, T. W., Hillyard, S. A., Krausz H. 1., and Galambos, R.: Human auditory evoked potentials. I : Evaluation of components, Electroenceph. Clin. Neurophysiol., 36, pp. 179-190, 1974

13) Picton, T. W. and Hillyard, S. A.: Human auditory evoked potentials. II : Effects of attention, Electroenceph. Clin. Neurophysiol., 36, pp. 191-199, 1974

14) Blenner, J. L. and Yingling, C. D.: Modality specificity of evoked potential augmenting / reducing, Electroenceph. Clin. Neurophysiol., 88, pp. 131-142, 1993

15) 丹羽真一, 鶴紀子: 事象関連電位, 新興医学出版社, 1997

16) 生理学大系V脳の生理学, 医学書院, 1967

17) Andreassi, J. L.: Psychophysiology: Human Behavior and Physiological Response Third Edition, Lawrence Erlbaum Associates, 1995

18) 柴崎浩, 米倉義晴: 脳のイメージングー脳のはたらきはどこまで画像化でき るか一，共立出版，1994

19) J. ハセット : 精神生理学入門, 東京大学出版会, 1987

20) 川人光男, 行場次朗, 藤田一郎, 乾敏郎, 力丸裕: 視覚と聴賞, 岩波書店, 1994 21) 力丸裕, 平松幸三, 高木興一, 山本剛夫: 騒音のレベル变化量が聴覚誘発緩 反応に与える影翌, 日本音㜅学会誌, Vol. 38, No. 2, pp. 91-99, 1982

22) 力丸裕, 平松幸三, 高木興一，山本剛夫: 聴賞誘発脳波（緩反応）に及ほす 騥音の立上がり速度の影響, 日本音響学会誌, Vol. 37, No. 2, pp. 55-64, 1981

23) Karlin, L.: Cognition, preparation, and sensory-evoked potentials, Psychological Bulletin, Vol. 73, No. 2, pp. 122-136, 1970

24) Kramer, A. F., Trejo, L. J., and Humphrey, D.: Assessment of mental workload with task-irrelevant auditory probes, Biological Psychology, 40, pp. 83-100, 1995

(1997年 6 月 30 日原稿受理, 1998 年 1 月 6 日採用決定 